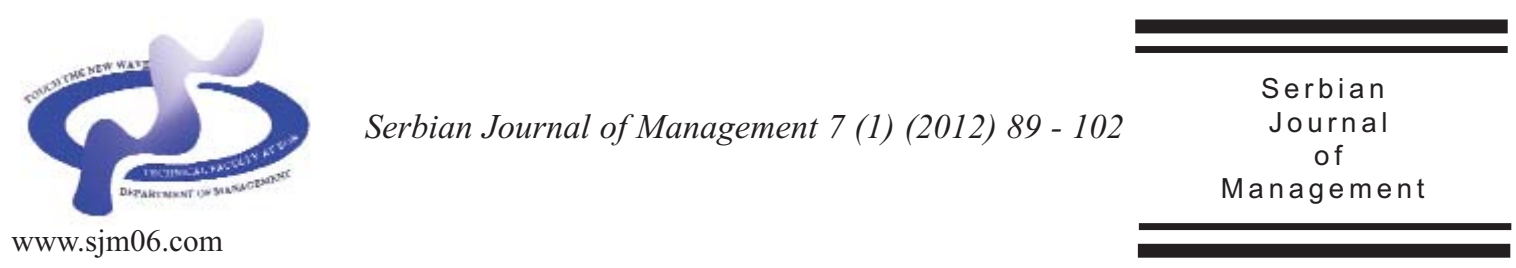

\title{
ANTECEDENTS OF ORGANIZATIONAL COMMITMENT OF BANKING SECTOR EMPLOYEES IN PAKISTAN
}

\author{
Abdullah* and Muhammad Ismail Ramay \\ Department of Management Sciences, International Islamic University Islamabad, \\ H-10, Islamabad, Pakistan
}

(Received 15 August 2011; accepted 12 December 2011)

\begin{abstract}
The aim of this study was to check the association of factors like work environment, job security, pay satisfaction and participation in decision making; with organizational commitment of the employees, working in the banking sector of Pakistan. Two hundred and fifteen (215) responses to questionnaire-based survey were collected from managerial and non-managerial employees, and analyzed. The analysis showed positive correlations between the dependent and independent variables. The relation between job security and organizational commitment was the most significant, indicating that a secure job can yield higher level of commitment. Work environment also had a significant relation with organizational commitment, showing that a healthy and friendly work environment may enhance an employee's commitment towards his work and organization. Pay satisfaction and participation in decision-making had low correlations with organizational commitment. Age and tenure seemed to affect the commitment of employees, with higher commitment shown for higher age and tenure; whereas gender did not show significant change in commitment level of employees.
\end{abstract}

Keywords: Organizational commitment, Work environment, Job security, Pay satisfaction, Participation in decision making.

\section{INTRODUCTION}

Organizational commitment is an issue of prime importance, especially to the management and owners of the organizations. Organizational commitment and job satisfaction are directly related to an organization's profitability and competitive position in the market. Organizational commitment directly affects employees' performance and is therefore treated as an issue of great importance. (Shore \& Martin, 1989; Meyer et al., 1989; Meyer et al., 1993; Siders et al., 2001; Meyer et al., 2002;

\footnotetext{
* Corresponding author: abdullah_alam@yahoo.com
}

DOI: $10.5937 /$ sjm1201089A 
Jaramillo et al., 2005; Vijayashree and Jagdischchandra., 2011).

Commitment is a sort of bond between an employee and the organization he is working for (Buchanan, 1974). The strength of this bond is dependent on various factors. This study will try to find the relation of some of these factors with organizational commitment. Organizational commitment has a strong relation with the employee behaviour. If an employee is committed to an organization, it would reduce the chances or occurrences of absenteeism and turnover (Igbaria \& Greenhaus, 1992). Commitment refers to an employee's willingness to work positively in an organization and his continuance to work for it (Mowday et al., 1982).

Organizations, like Banks, are considered to be one of the more stressed-out sectors in the World (Ebiringa, 2011). This is also the case with banking sector in Pakistan. Long working hours and inefficient use of technology are two of the main reasons of employees' lack of satisfaction and commitment. A few branches in Pakistan even work with over fifty (50) workers, whereas some of the branches still perform most of their work manually; with presentday technology available to them. Banking sector is one of the fanciest sectors for young business graduates. But the problems they face after joining the banking sector affect their commitment and in turn, raise issues like turnover, absenteeism and underperformance.

Banking sector has grown, by leaps and bounds, in the last 10 years or so, in Pakistan. With multinational and private banks coming into the banking sector, a lot of opportunities were created in the sector. These multinational and private banks recruited many experienced and qualified employees from the other competing banks, at much better salaries and packages. This affected the quality of workforce of the existing banks. So, it was thought significant to organize a study relating to the commitment of employees in the banking sector.

In Pakistan's culture, job security is considered an important pre-requisite for a job. Government jobs are considered more secure than private jobs because of the legal and cultural constraints which work in the favor of an employee. For example, it takes a lengthy procedure to terminate an employee from his job, even if enough evidence exists against him. For similar reasons, people prefer to get into government jobs because of the high level of job security offered. Also, handsome pay and packages add to the charm of such jobs. Apart from the monetary benefits, non-monetary benefits also play vital role in an employee's commitment towards his organization. Government jobs in Pakistan offer benefits like house rent (or house leasing), medical allowance, free medical facilities (for family also), easy loans (zero interest loans in case of bank employees), pensions, bonuses, regular increments etc. Such facilities securely tie an employee's job interest to the organization. The working environment is normally quite pleasant. People respect each other and are willing to help in work-related and other issues. Also good relations (working and after-work) exist between peers; and even managers and the employees. Participation in Pakistani culture is a variable that is, generally, not considered significant. Decisions are made by the higher management with no-say of the employees in the decision-making process. In most of the work-related issues, employees are not consulted for their input. Banking sector of Pakistan also bears similar attributes. 
Keeping the above discussion in mind, it was hypothesized that a significant relation should exist between organizational commitment and work environment, job security, pay satisfaction and participation in decision making.

Apart from the above-mentioned four antecedents, numerous other factors also affect organizational commitment significantly. But this study will focus, primarily, on work environment, job security, pay satisfaction and participation in decision making; as the antecedents of organizational commitment. A lot of work has been done, over the world, on the antecedents of organizational commitment. But very few researches (Chughtai \& Zafar, 2006; Khan et al., 2010; Abdullah, 2011) have been made on the organizational commitment of employees in Pakistan, especially in the banking sector. The objective of this research is to get an insight into the relationship between the four antecedents of organizational commitment (work environment, job security, pay satisfaction and participation in decision making) and their impact on the commitment of banking sector employees of Pakistan.

\section{REVIEW OF LITERATURE}

Literature on organizational commitment identifies several factors that have positive relationship with organizational commitment. Some of the factors, undertaken in this study, are given in the following section.

\subsection{Work Environment}

Work environment relates to the atmosphere in which an individual works in an organization. Individuals join organizations because of their needs and desires; and they expect an environment where their can nourish and also their needs get satisfied (Steers, 1977). Positive relations between peers and with management affect an employee's commitment to the organization. An employee's commitment towards the organization is affected by the nature of relations between colleagues. It has been noticed that conflicting relationships exist between peers; and between employees' and the management, which threaten organizational commitment. Organizations need to promote social activities, so that friendly relations can improve between the employees; and in turn, their commitment towards the organization excels (Kirmizi \& Deniz, 2009). Low performing employees are committed and comfortable in a less/non-threatened environment, whereas high performing employees need a challenging environment (Steers, 1977). Through data collection and its analysis, the extent of association of work environment with organizational commitment will be determined in this study.

H1: Better work environment increases organizational commitment.

\subsection{Job Security}

A secure job is an employees' requirement and wish. Job insecurity affects an employee's commitment to the organization. Employees' do not fancy risks and are willing to stay in an environment that provides satisfaction rather than optimized change (Kirmizi \& Deniz, 2009). Job security is generally not referred to, as an antecedent of organizational commitment; but this study has considered job security to be a factor of organizational commitment. An individual will be more committed to his 
job and the organization, if he feels himself secure. With the help of this study, an attempt will be made to study the relationship of job security with organizational commitment.

H2: Job security increases organizational commitment.

\subsection{Pay Satisfaction}

Pay satisfaction relates to an employee's mindset regarding the payment or compensation received for the services rendered. Pay may include basic salary and any bonuses or other economic benefits that an employee receives during employment. Individuals have certain needs and desires which they seek to get satisfied. The degree of an employee's commitment towards an organization also depends on the extent of financial and personal rewards. An organization which supports its employees mostly gets the desired feedback from the employees, where the employees feel an obligation to reciprocate (Folger \& Cropanzano, 1998; Meyer \& Allen, 1997). When an organization has employees having higher qualifications and experience, the organization might not be able to fulfill the employees' needs and financial desires; which makes the qualified and experienced individuals less committed to the organization (more committed to their professions, instead) (Steers, 1977). This study will attempt to study the relation of pay satisfaction with organizational commitment.

H3: Pay satisfaction increases organizational commitment.

\subsection{Participation in decision making}

Participation is an employees' role in the decisions of an organization. Participation of employees in the decision-making process and involving them in organizational plans and goals setting has positive impact on the employees' commitment towards the organization (Kirmizi \& Deniz, 2009). Involving employees in these processes, adds to their satisfaction and commitment. Higher employee participation leads to higher employee performance and organizational commitment in general (Meyer \& Allen, 1991). This study will try to establish an association between participation and organizational commitment.

H4: $\quad$ Participation in decision
making increases organizational
commitment.

\subsection{Organizational Commitment}

Commitment refers to the focus and the desire of attachment of an individual to a certain task or his work. Organizational commitment has been a topic widely researched over the years. Affective, continuance and normative commitment are the tools to measure organizational commitment (Meyer \& Allen, 1991; Dunham et al., 1994). Affective Commitment deals with the attachment of an employee with his organization and the organizational goals. (O Reily \& Chatman, 1986). Continuance Commitment deals with the commitment to pursue working in an organization because of the inter-employee relations and other non-transferable investments like pensions (retirement benefits etc.) (Reichers, 1985). ẩ ormative Commitment refers to a sort of an obligation on the part of an employee, due to which he is willing to stay (or continue working) in an organization. Affective and continuance 


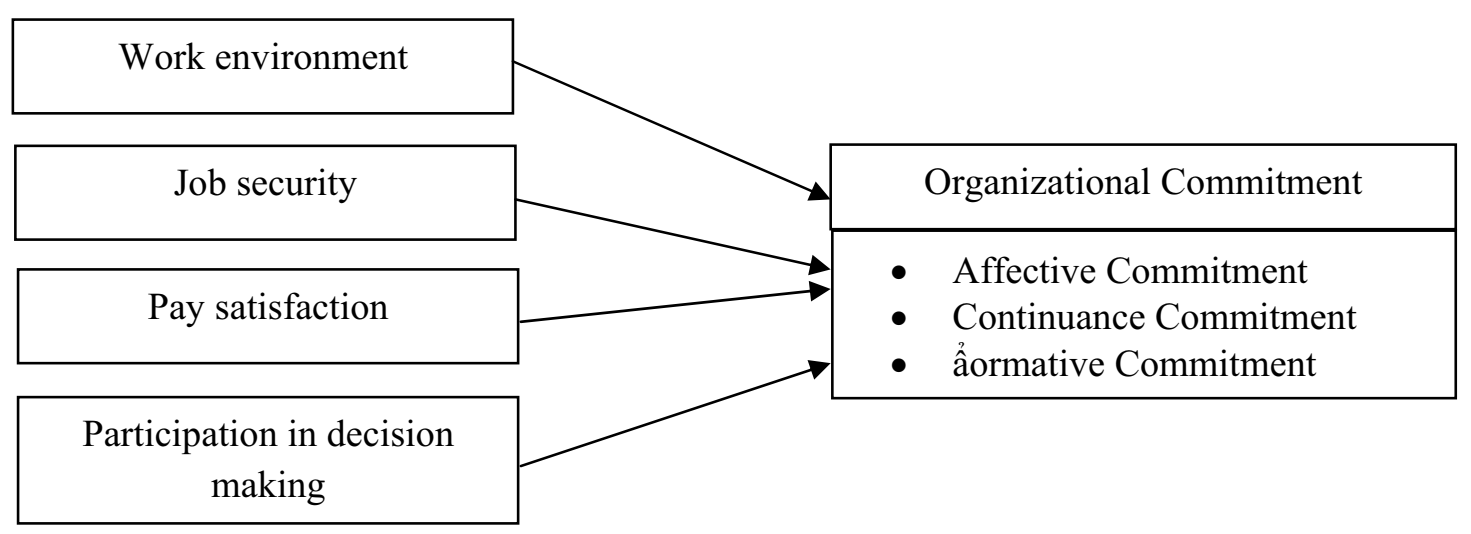

Figure 1. Hypothesized relationship of Organizational commitment with Work environment, Job security, Pay satisfaction and Participation in decision making (Source: The above framework has been self-hypothesized)

commitment have been much researched by people, over the globe. But normative commitment is one of the less-researched types of commitment. In this study, organizational commitment was not taken in relation to its measurement tools (affective, continuance and normative commitment), rather it was studied as a complete unit.

Hence, organizational commitment is a topic of vital importance to managers and researchers and this study will try to find the relationship of organizational commitment with work environment, job security, pay satisfaction and participation in decision making (see Figure 1).

\section{METHODOLOGY}

\subsection{Subjects}

Data was collected from the major cities of Pakistan. Questionnaires were distributed to employees of the banking sector. These banks included various private, public and multi-national banks. A total of 350 questionnaires were floated, out of which
230 were returned. The response rate was $66 \%$. The high return rate was due to the fact that we personally went to different banks and distributed the questionnaires.

\subsection{Procedure}

The questionnaire included some background knowledge and information related to the current study and its purpose. The respondents were also assured of confidentiality in this regard. The respondents were also briefed and guided about the scope of this research. They were motivated to fill the questionnaire in a manner that could reflect their true perceptions regarding the questions.

Out of the 230 received responses, 15 questionnaires were rejected on various grounds. A total of 215 questionnaires were analyzed using SPSS 17.0. We used confirmatory factor analysis to check if the data fitted the model adequately, then Aẩ OVA and correlation analysis was performed to study the hypotheses under study. 


\subsection{Measures}

Primary data was collected using questionnaire survey. The questionnaire comprised of two sections, the demographics of the respondents and the section regarding organizational commitment and its antecedents.

Organizational commitment was measured through 18 items taken from the study of Meyer, Allen \& Smith (1993). Work Environment was measured using items from studies of Mowday et al. (1979) and Ashford et al. (1989), Stallworth (2004). 7 items related to job security were taken from the questionnaire used by Hellgren et al. (1999); while pay satisfaction was measured by 5 items using questions from the researches of White \& Ruh (1973), Hackman \& Oldham (1976), and Uygur \& Kilic (2009). Participation in decision making was measured by 7 items taken from the questionnaires of Mohr (1971), Hrebiniak (1974), and Van Veldhoven \& Meijman (1994). All the items were measured using five point Likert scale ranged from strongly disagreed (1) to strongly agreed (5). All the scales had Cronbach's alphas above 0.70. The questionnaire is given in Appendix A.

\section{RESEARCH ANALYSIS}

\subsection{Demographic Characteristics of the Respondents}

One hundred and seventy (170) male $(79 \%)$ and 45 female $(21 \%)$ respondents participated in the survey. The age of majority of the respondents was between 30 years and 40 years. The educational qualification of $21 \%$ of the respondents was bachelors, $57 \%$ had master level education and $4 \%$ of the respondents had above masters level of education.

The monthly income of majority of the respondents was between Rs. 31000 and Rs. 40000. $48 \%$ of the respondents had $1-5$ years of experience, while $28 \%$ of them had more than 10 years of working experience in banking sector.

\subsection{Descriptive Analysis}

The highest mean of 3.24 (rounded off) was calculated for Job security which shows that employees feel that their jobs were secure. The calculated mean for other independent variables (work environment, pay satisfaction and participation in decision making) are 3.24, 3.11 and 3.13 respectively; which indicates that employees are mildly satisfied with these factors. The mean value of 3.16 for the dependent variable i.e., organizational commitment shows that employees are slightly committed towards their organizations.

\subsection{Results}

The hypothesized model in figure 1 was tested using LISREL 8.80 (Joreskog \& Sorbom, 2006). The model is given in Figure 2.

The model indicates that all the four antecedents (work environment, job security, pay satisfaction and participation in decision making) are strong predictors of organizational commitment.

The LISREL goodness of fit statistics supported this model. The chi-square $(\chi 2)$ of $2.75(\mathrm{df}=2)$ was significant. The goodness of fit index (GFI) was .99, the adjusted goodness of fit index (AGFI) being .97, root mean square error of approximation (RMSEA) being 0.04 and the standardized 


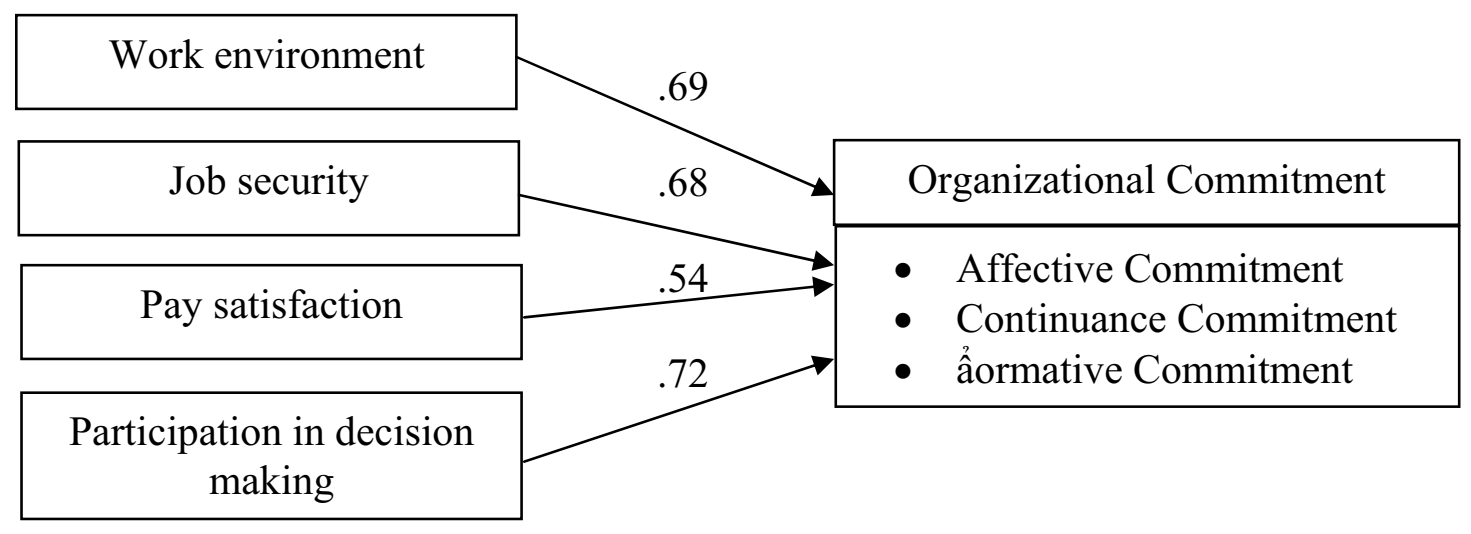

Figure 2. Results of path analysis showing relationship between work environment, job security, pay satisfaction and participation in decision making; as antecedents of Organizational commitment

root mean square residual (SRMR) was .02. These statistics indicate that the data fit the model very well.

ẩ o significant differences were found in organizational commitment by gender. Commitment means of 3.18 and 3.10 were recorded for male and female respondents, respectively. However, organizational commitment $\mathrm{F}(3,211)=4.2, \mathrm{p}<.01, \mathrm{r}=.11$, differed significantly with age; with respondents having ages between 51 and 60 years showing maximum commitment. Also, organizational commitment $\mathrm{F}(7,203)=4.72$, $\mathrm{p}<.001, \mathrm{r}=.10$, differed significantly with tenure; with respondents having tenures more than 20 years showing maximum commitment.

Table 2 gives the means, standard deviations and correlations among the variables under study.

The relationship strength between the variables was determined using "Kendall's

Table 1. Means, Standard deviations and Correlations between major variables in the study

\begin{tabular}{|c|c|c|c|c|c|c|c|c|c|c|}
\hline & Mean & SD & 1 & 2 & 3 & 4 & 5 & 6 & 7 & 8 \\
\hline 1. Age & & & 1.00 & & & & & & & \\
\hline 2. Gender & & & $-.18^{* *}$ & 1.00 & & & & & & \\
\hline 3. Tenure & & & $.56^{* *}$ & $-.14 *$ & 1.00 & & & & & \\
\hline 4. Organizational commitment & 3.16 & .43 & $.11 *$ & -.05 & .10 & $(.73)$ & & & & \\
\hline 5. Work environment & 3.24 & .59 & .08 & -.06 & .10 & $.38 * *$ & $(.77)$ & & & \\
\hline 6. Job security & 3.24 & .51 & $.15^{* *}$ & -.07 & $.12 *$ & $.42 * *$ & $.33^{* *}$ & $(.71)$ & & \\
\hline 7. Pay satisfaction & 3.11 & .56 & $.14 *$ & $-.15^{*}$ & $.12 *$ & $.23 * *$ & $.30 * *$ & $.31 * *$ & $(.70)$ & \\
\hline 8. Participation in decision making & 3.13 & .81 & $.20 * *$ & -.01 & $.19 * *$ & $.18^{* *}$ & $.41 * *$ & $.35^{* *}$ & $.27 * *$ & (.91) \\
\hline
\end{tabular}

Figures in parentheses represent the Cronbach's alpha values for the scales.

** Correlation is significant at $p<.01$

* Correlation is significant at $p<.05$ 
tau-b correlation coefficients matrix". This study found positive significant relationship between the dependent variable (organizational commitment) and the independent variables (work environment, job security, pay satisfaction and participation in decision making), as indicated in the previous researches on the topic.

The correlation coefficients for age, gender and tenure (with organizational commitment) were $.11,-.05$ and .10 respectively. This shows that age and tenure have their parts (although small) in determining an employee's commitment towards his organization. Gender had a negative relation with organizational commitment. Correlation coefficient of work environment with organizational commitment was found to be .38. Job Security also showed positive and significant relationship with commitment; the value being .42. This certifies our hypotheses that better work environment and job security induce organizational commitment in the employees.

Pay satisfaction had a positive and modest correlation with organizational commitment; showing correlation coefficient of .23, which validates our proposition that pay satisfaction is a predictor of organizational commitment of the banking sector employees of Pakistan. Participation in decision making had a correlation of .18 with organizational commitment. This confirmed our hypothesis that participation in decision making increases organizational commitment.

All the correlations were positive. The highest correlation was found for job security and the lowest for participation in decision making.

\section{CONCLUSION}

Statistical analysis indicates that the employees working in the banking sector feel that their jobs are somewhat secure. Also they are provided a reasonably healthy working environment. The employees are slightly satisfied with the pays and their say in work-related decisions. People working in the banking sector are mildly committed towards the organizations they are working for and feel that they have a sense of belonging towards it.

Employees having longer tenures and ages show more commitment than the employees having smaller tenures with the organizations and younger in age respectively. This is easy to understand because employees who have spent most of their lives with the organization should exhibit high commitment. Also with age, alternative opportunities for employees become limited; thereby enhancing their commitment with the organization they are working for.

Correlation analysis confirmed the four hypotheses undertaken in this study. The highest correlation for job security may indicate that if the employees are offered secure jobs through fair decision-making and sound policies, their commitment level is expected to rise. Also, the average correlation between work environment and organizational commitment may indicate that friendly work environment and cooperation on the part of managers adds to the employees' commitment. Pay satisfaction and participation in decision making have low correlations with organizational commitment which may mean that these factors might not highly contribute towards employees' commitment towards their organizations. 
Pakistan, with its cultural settings, has a lot of space for research. In future, organizational commitment may be studied in relation to its three components (affective, continuance and normative) and the relation between the three components may be established in Pakistani settings.

\title{
ПРЕДУСЛОВИ ОРГАНИЗАЦИОНЕ ПОСВЕЪЕНОСТИ ЗАПОШЉЕНИХ У БАНКАРСКОМ СЕКТОРУ У ПАКИСТАНУ
}

\author{
Abdullah and Muhammad Ismail Ramay \\ Department of Management Sciences, International Islamic University Islamabad, \\ H-10, Islamabad, Pakistan
}

\begin{abstract}
Извод
Циљ овог истраживања био је да се испита повезаност фактора као што су пословно окружење, безбедност на радном месту, задовољство послом и учешће у одлучивању, са организационом посвећеношћу запослених, који раде у банкарском сектору Пакистана. Извршено је анкетирање 215 запошљених на позицијама менаџмента и осталим управљачким позицијама. Анализа добијених резултата је показала позитивну корелацију између зависних и независних варијабли. Релација између сигурности радног места и организационе посвећености је била најзначајнија, што индицира да сигурно радно место може дати већу посвећеност запошљеног. Радно окружење је такође имало значајну релацију са организационом посвећеношћу, што показује да здраво и пријатељско радно окружење може побољшати посвећеност запошљеног према раду и организацији. Задовољство платом и учешће у процесима одлучивања има ниску корелацију са посвећеношћу. Године старости и време проведено у организацији имају утицаја на посвећеност запошљених, виша посвећеност је изражена код старијих радника са више радног искуства. С друге стране, пол испитаника није утицао на степен посвећености организацији.
\end{abstract}

Кључне речи: Организациона посвећеност, Радно окружење, Безбедност радног места, Задовољство платом, Учешће у одлучивању.

\section{References}

Abdullah (2011). Evaluation of Allen and Meyer's organizational commitment scale: A cross-cultural application in Pakistan. Journal of Education and Vocational Research, 1(3): $80-86$.
Allen, â.J., \& Meyer, J.P. (1990). The measurement and antecedents of affective, continuance and normative commitment to the organization. Journal of Occupational Psychology, 63: $1-18$.

Ashford, S.J., Lee, C., and Bobko, P. (1989). Content, causes and consequences of 
job insecurity: A theory-based measure and substantive test. Academy of Management Journal, 32(4): 803 - 829.

Buchanan II,B. (1974). Building organizational commitment: The socialization of managers in work organizations. Administrative Science Quarterly, 19: 533 - 546.

Chughtai, A., \& Zafar, S. (2006). Antecedents and consequences of organizational commitment among Pakistani university teachers. Applied H.R.M. Research, 11(1): $39-64$.

Dunham, R.B., Grube, J.A., \& Castaneda, M.B. (1994). Organizational commitment: The utility of an integrative definition. Journal of Applied Psychology, 79: 370 380 .

Ebiringa, O. T. (2011). Benchmarking incidence of distress in the ẩ igerian banking industry on Altman scale. Serbian Journal of Management, 6(2): 221-230.

Folger, R., \& Cropanzano, R. (1998). Organizational justice and human resource management. Beverly Hills, CA: Sage.

Hackman, J.R., \& Oldham, G.R. (1976). Motivation through the design of work: Test of a theory. Organizational Behavior and Human Performance, 16: 250 - 279.

Hellgren, J., Sverke, M., \& Isaksson, K. (1999). A two-dimensional approach to job insecurity: Consequences for employee attitudes and well-being. European Journal of Work and Organizational Psychology, 8: $179-195$.

Hrebiniak, L.G. (1974). Effects of job level and participation on employee attitudes and perceptions of influence. 17(4): $649-$ 662.

Igbaria, M., \& Greenhaus, J.H. (1992). Determinants of MIS employees turnover intensions: A structured equations model. Communication of the ACM, 35(2): 35 - 49.
Jaramillo, F., Mulki, J.P., \& Marshall, G.W. (2005). A meta-analysis of the relationship between organizational commitment and salesperson job performance: 25 years of research. Journal of Business Research, 58: 705 - 714.

Jöreskog, K.G. \& Sörbom, D. (2006). LISREL 8.80 for Windows [Computer Software]. Lincolnwood, IL: Scientific Software International, Inc.

Khan, M.R., Ziauddin, Jam, F.A. \& Ramay, M.I. (2010). The impacts of organizational commitment on employee job performance. European Journal of Social Sciences, 15(3): 292 - 298.

Kirmizi, A., \& Deniz, O. (2009). The organizational commitment of IT professionals in private banks. European and Mediterranean Conference on Information Systems, July 13 - 14, 2009.

Meyer, J.P., \& Allen, ẩ .J. (1991). A threecomponent conceptualization of organizational commitment. Human Resource Management Review, 1: 64 - 89.

Meyer, J.P., \& Allen, ẩ.J. (1997). Commitment in the workplace: Theory, research and application. Thousand Oaks, CA: Sage Publications.

Meyer, J.P., Allen, ẩ.J., \& Smith, C.A. (1993). Commitment to organizations and occupation: Extensions and test of a threecomponent conceptualization. Journal of Applied Psychology, 78: 538 - 551.

Meyer, J.P., Paunonen, S.V., Gellaty, I.R., Goffin, R.D., \& Jackson, D.ẩ . (1989). Organizational commitment and job performance: It's the nature of the commitment that counts. Journal of Applied Psychology, 74: 152 - 156.

Meyer, J.P., Stanley, D.J., Herscovitch, L., \& Topolnytsky, L. (2002). Affective, continuance and normative commitment to the organization: A meta-analysis of 
antecedents, correlates and consequences. Journal of Vocational Behavior, 61: 20 - 52.

Mohr, L.B. (1971). Organizational technology and organizational structure. Administrative Science Quarterly, 16: 444 459.

Mowday, R.T., Porter, L.W., \& Steers, R.M. (1982). Employee-organization linkages: The psychology of commitment, absenteeism and turnover. ẩ ew York Academic Press.

Mowday, R.T., Steers, R.M., \& Porter, L.W. (1979). The measurement of organizational commitment. Journal of Vocational Behavior, 14: 224 - 247.

O'Reilly, III,C., \& Chatman, J. (1986). Organizational commitment and psychological attachment: The effects of compliance, identification and internalization on prosocial behavior. Journal of Applied Psychology, 71(3): 492 - 499.

Riechers, A.E. (1985). A review and reconceptualization of organizational commitment. Academy of Management Review, 10: 465 - 476.

Shore L.M., \& Martin, H.J. (1989). Job satisfaction and organizational commitment in relation to work performance and turnover intentions. Human Relations, 42: 625 - 638.

Siders, M.A., George, G., \& Dharwadkar, R. (2001). The relationship of internal and external commitment foci to objective job performance measures. Academy of Management Journal, 44(3): 570 - 579.

Stallworth, L. (2004). Antecedents and consequences of organizational commitment to accounting organizations. Managerial Auditing Journal, 19(7): 945 - 955.

Steers, R.M. (1977). Antecedents and outcomes of organizational commitment. Administrative Science Quarterly, 22(1): 46 $-56$.

Uygur, A., \& Kilic, G. (2009). A study into organizational commitment and job involvement. Ozean Journal of Applied Sciences, 2(1): $113-125$.

Van Veldhoven, M., \& Meijman, T.F. (1994). Het meten van psychosociale arbeidsbelasting met een vragenlijst: De Vragenlijst Beleving en Beoordeling van de Arbeid [The measurement of psychosocial strain at work: The questionnaire experience and evaluation of work]. Amsterdam: ẩ IA

Vijayashree, L., Jagdischchandra, M.V. (2011). Locus of control and job satisfaction: PSU Employees. Serbian Journal of Management, 6(2): 193-203..

White, J.K., \& Ruh, R.A. (1973). Effects of personal values on the relationship between participation and job attitudes. Administrative Science Quarterly, 18: 506 514. 


\section{Appendix A}

\section{Antecedents of Organizational Commitment}

\section{A Study of Banking Sector of Pakistan}

\section{Demographic Questions:}

1. Age: years

3. Qualification: Graduate/Master/MS/Ph.D./Others

5. Experience: years

7. Position in the Organization
2. Gender: Male/Female

4. Salary per month (Optional):

6. Years with Current Organization:

\section{Appendix 1 : Organizational Commitment}

Affective Commitment

1. I would be very happy to spend the rest of my career in this organization.

2. I really feel as if this organization's problems are my own.

3. I do not feel like 'part of my family' at this organization.

4. I do not feel 'emotionally attached' to this organization.

5. This organization has a great deal of personal meaning for me.

6. I do not feel a strong sense of belonging to this organization.

\section{Continuance Commitment}

7. It would be very hard for me to leave my job at this organization right now even if I wanted to.

8. Too much of my life would be disrupted if I leave my organization.

9. Right now, staying with my job at this organization is a matter of necessity as much as desire.

10. I believe I have too few options to consider leaving this organization. 
11. One of the few negative consequences of leaving my job at this organization would be the scarcity of available alternative elsewhere.

12. One of the major reasons I continue to work for this organization is that leaving would require considerable personal sacrifice.

Iormative Commitment

13. I do not feel any obligation to remain with my organization.

14. Even if it were to my advantage, I do not feel it would be right to leave.

15. I would feel guilty if I left this organization now.

16. This organization deserves my loyalty.

17. I would not leave my organization right now because of my sense of obligation to it.

18. I owe a great deal to this organization.

\section{Appendix 2 : Work Environment}

19. I frequently socialize with my co-workers outside the workplace.

20. My superiors regularly invite me to socialize outside the workplace.

21. I feel that I have equal status with my peers in the organization.

22. I find that my values and the organization's values are very similar.

23. For me, this is the best of all possible organizations for which to work.

24. I talk up this organization to my friends as a great organization to work for.

25. I have considerable opportunity for independence and freedom in how I do my job.

\section{Appendix 3 : Job Security}

26. I feel that the organization can provide me with a stimulating job content in the near future.

27. I feel uneasy about losing my job in the near future.

28. My pay development in this organization is promising.

29. I am worried about having to leave my job before I would like to.

30. My future career opportunities in the organization are favorable.

31. There is a risk that I will have to leave my present job in the year to come.

32. I believe that the organization will need my competence also in the near future. 


\section{Appendix 4 : Pay satisfaction}

33. I am generally satisfied with the amount of pay and fringe benefits I receive in this organization.

34. I am paid fairly for what I contribute to this organization.

35. I am paid less than others who are doing similar work.

36. I will stay overtime to finish a task, even if I am not paid for it.

37. I would go on working in this organization, even if I did not need to earn money.

\section{Appendix 5 : Participation in decision making}

38. My supervisor/manager asks me for my opinions and thoughts when determining my work objectives.

39. I feel involved in important decisions in my organization.

40. Employees who will be affected by decisions are asked for their inputs.

41. I feel free to suggest changes in my job.

42. I participate in decision-making with regard to work-related issues.

43. I have a say in what is, and what is not, a part of my job.

44. I have influence over the division of work over my colleagues and myself. 